\title{
BESONDERHEDE AANGAANDE 'N AANTAL GEBOUE OP DIE TERREIN VAN DIE HUIDIGE VERDEDIGINGSHOOFKWARTIER, POTGIETERSTRAAT, PRETORIA
}

Dié gebou voer ons terug na die sewentiende eeu, dié eeu wararin - ook op militêre gebied - dié hegte grondslae gelê is waarop ons tot vandag toe voortbou.

Maar daar is, oor die lengte en breedte van ons land versprei, ook ander eertydse verdedigingswerke en militêre geboue wat aan ander aspekte van ons roemryke militêre verlede verbind is.

Die Kasteel die Goeie Hoop, in die Moederstad van Suid-Afrika, is ongetwyfeld die waardevolste militêr-historiese boukundige erfenis waaroor ons vandag beskik. In laasgenoemde opsig is die oudste gedeelte van ons hedendaagse Verdedigingshoofkwartier, Potgieterstraat, Pretoria, met sy bygeboue en 'n groep voormalige offisierswonings ' $n$ gebouegroep wat vermoedelik uniek in ons Republiek is.

Al hierdie geboue herinner ons aan die militêre verlede, aan die Zuid-Afrikaansche Republiek, aan die weergalose Staatsartillerie en aan die doelbewuste strewe van Staatspresident S. J. P. Kruger, Genl. P. J. Joubert, KG, ZAR, en hul mede-landsburgers om die vryheid en onafhanklikheid van Transvaal, indien dit nodig sou word, met die wapen te verdedig.

\section{Die Terrein}

Aan die suidekant van Pretoria, begrens deur Artillerieweg en die spoorlyn in die noorde, Tweedestraat in die weste, Dequarweg aan die suide- en Potgieterstraat aan die oostekant, lê 'n terrein wat reeds ongeveer negentig jaar in die teken van militêre opleiding-, huisvesting of soortgelyke aangeleenthede gestaan het.

Tans staan hierdie terrein in die teken van militêre aangeleenthede met betrekking tot die Republiek van Suid-Afrika. Dit is die terrein waarop die Verdedigingshoofkwartier van 'n vrye en onafhanklike republiek verrys. En in die verlede?

In die tyd van Staatspresident T. F. Burgers, voor die anneksasie van Transvaal in April 1877, was die hoofkwartier van die toenmalige Transvaalse Artilleriekorps op die hoek van Paleis- en Vermeulenstraat gevestig. Daar, naby die historiese Kerkplein, was 'n kaserne en 'n magasyn. In dié omgewing het militêre bevele weerklink en is militêre oefeninge gehou'.

Die terrein aan Potgieterstraat, oorspronklik 'n gedeelte van die plaas Elandspoort no. 193 wat aan Staatspresident M. W. Preterius behoort het, het op 18 September 1860 goewermentseiendom geword ${ }^{2}$. Waarvoor dit in die sestiger en sewentiger jare deur die Staat aangewend is, is onbekend ${ }^{3}$.

2 'n Militêre Kamp

Op $4 \mathrm{Mei} 1877$ het die eerste gereelde Britse troepe op Pretoria aangekom. 'n Kamp is opgeslaan ten suide van die dorp en op 'n kaart van Pretoria wat van 14. November 1879 , dateer en in die plaaslike kantoor van die Royal Engineers geteken is, is sowel die kampterrein as die Britse militêre geboue aangedui.

Op 'n skets, wat op 15 April 1880 aan die toenmalige Britse Administrateur van Transvaal voorgelê is met die oogmerk om die noordoostelike grens van die bebestaande Military Camp of die Camp or Ordinance Ground vas te stel, kom dieselfde terrein weer voor.

Beoog is om 'n gedeelte van Visagiestraat tot die hoek van Kochstraat (vandag Bosmanstraat) as noordgrens van die kamp te aanvaar. In die verlengde van Visagiestraat het die noordgrens ongeveer $\frac{2}{3}$ myl in westelike rigting geloop om vandaar met 'n boog by die westelike uitloper van Magasynheuwel aan te sluit.

Vanaf hierdie punt het die suidgrens van die kampterrein tot 'n punt in die poort tussen Magasynheuwel en Schanskop geloop, terwyl die oosgrens vandaar tot ongeveer die kruising van Maré- en Kochstraat tot op die hoek van laasgenoemde en Visagiestraat aangedui is. 


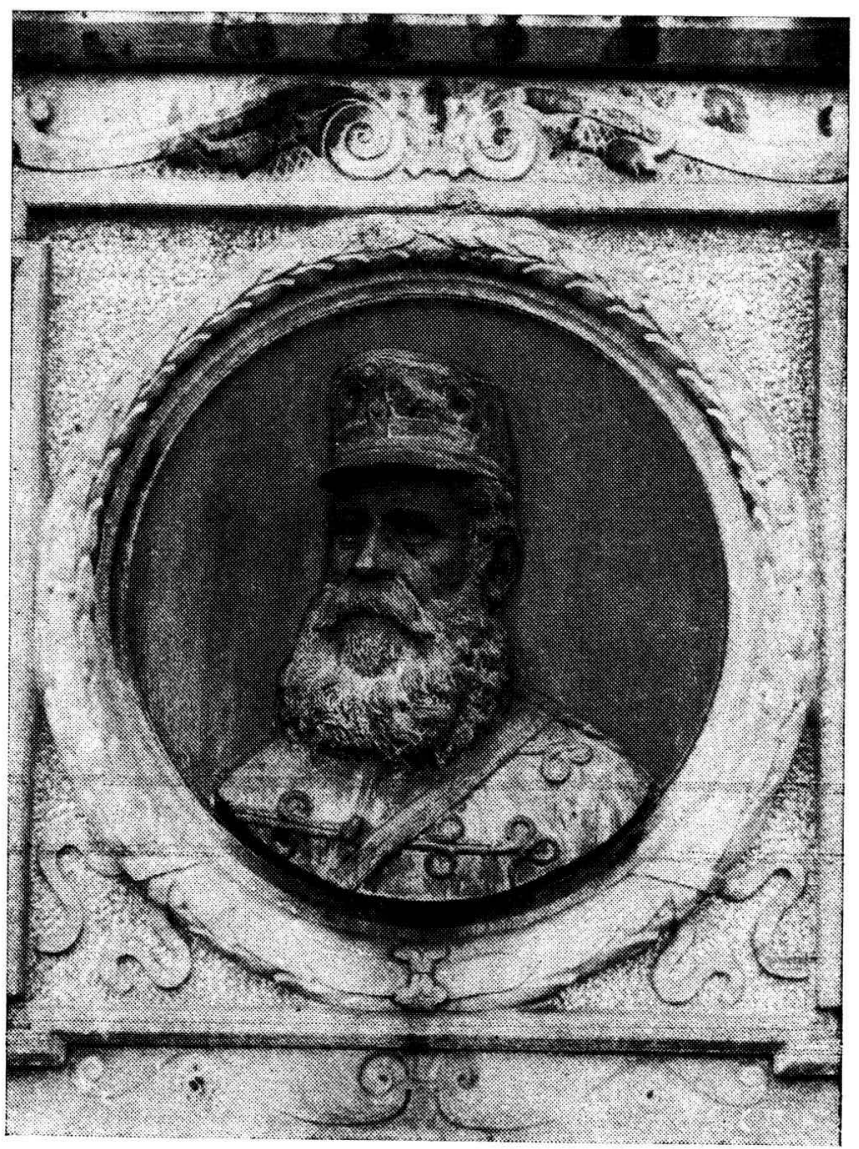

Lt.-kol./Lt.-Col. H. P. N. Pretorius.

Foto: Militêr-Historiese en Argivale Dienste Photograph: Military Historical and Archival Services. 
Op hierdie terrein was, volgens laasgenoemde skets, o.m. 'n magasyn en 'n aantal militêre geboue, terwyl oos van die toentertyd bestaande Potchefstroom-pad, onderkant Schanskop, 'n berede infanteriekamp gevestig was.

$\mathrm{Na}$ die vredesluiting van 1881 dra die Uitwoerende Raad aan kommandant-generaal P. J. Joubert op om 'n artillerierskorps te stig wat, onder die benaming Artilleriekorps van de Zuid-Afrikaansche Republiek, kragtens Wet no. 4, 1881 tot stand kom. In 1884 het hierdie eenheid, nou bekend as die Transvaalsche Rijdende Artillerie, onder bevel van die bekende kmdt. Henning P. N. Pretorius, uit die bevelvoerder, 'n tweetal luitenante en ongeveer 100 manskappe bestaan.

Hierdie eenheid is op die terrein van die voormalige Britse militêre kamp en aanvanklik in bestaande geboue gehuisves ${ }^{5}$.

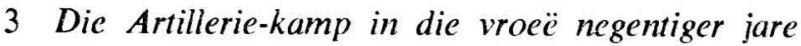

Op 3 Oktober 1892 het die regering aan genl. P. J. Joubert en die Hoof van Openbare Werke, mnr. S. Wierda, opgedra om die terrein en geboue van die Artilleriekamp aan Potgieterstraat te inspekteer. Uit die kommissie-verslag van 25 Februaric 1893 blyk dat die bestaande Veldtelegrafie-geboue en die ammunisie-magasyn herstel kan word. Die stalle is as ondoeltreffend beskrywe, terwyl die wonings van die onderoffisiere en die slaapsale van die manskappe, sowel uit 'n oogpunt van verspreiding as ten opsigte van die gesondheid van die bewoners, aan kritiek onderwerp is.

Die opstellers van die verslag was van mening dat die bestaande toestand nie kon bly voortbestaan nie en het aanbeveel dat die kampterrein weliswaar moet bly waar dit is, maar dat die bestaande geboue oor 'n tydperk van drie jaar geleidelik vervang moet word'.

Kort voordat hierdie verslag aan die Staatsekretaris voorgelê is. het lt. P. C. Paff, van die Afdeling Veldtelegrafie, vir meer geriewe gepleit en in Februarie, na aanhoudende reën, verklaar dat die kampgeboue ongesond vir mens en dier is ${ }^{7}$.

Nog 'n bolangrike faktor wat veranderings in die kamp gebiedend gemaak het, was die beoogde uitbreiding van die korps Rijdende Artillerie en Politie na 200 man.

In laasgenoemde verband stuur die korps se administrateur op 24 Februarie 1893 'n lys van geboue aan genl. Joubert wat, ook met betrekking tot kanon- en ander aankope, benodig is ${ }^{8}$.

\section{Nuwe geboue? Wetgewing}

In sy skrywe stel die administrateur die volgende geboue voor:

a. 'n Hoofgebou, bestaande uit 'n offisiers-wagkamer en 'n wagvertrek vir manskappe, 3 kamers vir arrestante, 'n saal vir 200 manskappe, 'n kombuis, 'n proviandgebou, 'n eetsaal, 'n klaskamer, 'n kantien, kamers vir offisiere, 'n hospitaal, 'n kommandants- en administrateurskantore, 'n kantoor vir die kwartiermeester, 'n pakkamer, wasgeriewe, e.d.m.

b. Stalle, t.w. 'n offisierstal (30 perde), 'n manskappestal (200 perde), 'n hospitaalstal (11 perde), voer- en mielie-opslagplekke en 'n vertrek vir saals en tuie.

c. Magasyne, t.w. 'n kanonhuis $\left(100^{\prime} \times 30^{\prime}\right)$, 'n wacnhuis $\left(100^{\prime} \times 30^{\prime}\right)$, 'n ammunisiemagasyn $\left(100^{\prime} \times 30^{\prime}\right)$, 'n kleremagasyn $\left(60^{\prime} \times 30^{\prime}\right)$, 'n gereedskapkamer $\left(10^{\prime} \times 12^{\prime}\right)$ en 'n pakkamer $\left(14^{\prime} \times 20^{\prime}\right)$.

d. 'n Smidswinkel vir die hoef- en wapensmid, 'n skrynwerkerswerkplaas en 'n woonhuis.

e. ' $n$ Drilsaal $(50$ ' $\times 50$ ').

f. 'n Offisiersgebou, bestaande uit wonings vir die kommandant, die administrateur, 4 getroude luitenante, 4 ongetroude luitenante, badkamers, e.d.m.

g. Vir die Afdeling Veldtelegrafic 'n klaskamer, 'n magasyn, 'n slaapsaal vir 15 manskappe, 2 badkamers, e.d.m. 
Op 19 Junie 1893 het die Volksraad, na aanleiding van 'n mosie wat op 15 Junie 1893 deur lede A. D. W. Wolmarans en P. G. Roos ingedien is, besluit om van die orde af te wyk ten einde die wenslikheid te bespreek om aan die regering op te dra om 'n behoorlike ondersoek na die inwendige toestand en die beheer van die Artilleriekamp in te stel. Daar is besluit om aan die Uitvoerende Raad op te dra om 'n kommissie van drie lede te benoem ten einde bogenoemde ondersoek uit te voer en daarna die bevindings te rapporteer'.

Op 31 Julie 1893 is die verslag, soos opgestel deur lede A. D. W. Wolnnarans, W. F. Pretorius en J de Clerq, A. seun in die Volksraad ter tafel gelê. Aaangaande die toestand, bestemming en inhoud van die geboue in die Artilleriekamp is o.m. soos volg gerapporteer:

a. Die geboue verkeer in 'n besonder onbevredigende toestand sodat die gewere en 'n gedeelte van die ammunisie nie roesvry kan bly nie.

b. Die kanonne en kanonwaens staan gedeeltelik onder 'n afdak, is nie beskut teen weersinvloede nie en ly skade.

c. Die klerasie- en kanontuiemagasyne is reeds te klein, ontoereikend verlig en in so 'n toestand dat reënwater op verskeie plekke kan binnedring en genoemde materiaal beskadig.

d. Die perdestalle, die offisierswonings, die slaapsale, die woning van die magasynmeester en die telegrafisteskool verkeer in 'n toestand wat dringende verbetering vereis.

Met betrekking tot die bestaande toestand van die geboue het die kommissie onomwonde op verbetering aangedring en terselfdertyd aanbeveel dat die Rijdende Artillerie van die Polisie geskei word om, op dié wyse, 'n suiwer militêre Staande Mag daar te stel. 'n Konsep-wet in dier voege is op 8 Mei 1895 aan die Volksraad voorgelê. As gevolg van die Volksraadsbesluit om die getalsterkte van die beoogde Korps te vermeerder, is die konsep-wet op 5 Mei 1896 weer na die kommissie verwys en op 18 Mei van dieselfde jaar nogmaals ter tafel gelê. Goedkeuring van die konsep-wet het op 18 Mei 1896 gevolg en hiermee was die grondslag gelê van 'n toekomstige keurkorps wat, soos in art. 1. van die wet verklaar is, bedoel was om:

a. Die kern te vorm van die krygmag van die Republiek en elke oomblik gereed moet wees om uit te ruk.

b. Die manskappe op so 'n wyse militêr op te lei dat hulle, na die verstryking van hul dienstyd, bekwaam sal wees om, indien nodig, as onderoffisier te kan optree.

c. Die manskappe deur skoolonderrig sodanig op te lei dat hulle na 'n dienstyd van drie jaar bekwaam sal wees om poste in die Staatsdiens te kan beklee ${ }^{\mathrm{ic}}$.

\section{Bouplanne neem ' $n$ vaste vorm aan}

Terwyl die reorganisasie en uitbreiding van die Artilleriekorps sy beslag in 1896 gekry het, het die pogings om die bestaande kampgeriewe te verbeter nie stilgestaan nie.

Op 3 Februarie 1894 het argitek K. van Rijsse, van die Departement van Openbare Werke, met die opstel van 'n memorie van toeligting met betrekking tot die kampinrigting van die Rijdende Artillerie-korps van 200 man gereed gekom".

In hierdie belangrike dokument het Van Rijsse sy planne soos volg ontvou:

a. As kampterrein beveel hy dieselfde terrein aan wat tans, in 1894, in gebruik is en tussen die bestaande Potgieterstraat, Maréstraat, die terrein van die Volkshospitaal en die verlengde van Kortestraat geleë en deur hom as een droge gravelachtige tamelijk hooge grond en niet sterk hellend beskrywe is.

b. Hy spreek die mening uit dat, as gevolg van bogenoemde omstandighede, die gelykmaak van die voorplein en die drilveld nie veel moeilikhede sal oplewer en die fonderings van op te rigte geboue nie buitensporig duur sal word nie. 
c. Ten opsigte van die groepering van die kampgeboue stel hy voor om die paviljoenstelsel, wat uit praktiese en higiëniese redes in Europa en Amerika in gebruik is en wat syns insiens uitermate geskik vir ons klimaatsomstandighede is, toe te pas.

d. Daar moet nie alleen op die doeltreffende groepering van die kampgeboue gelet word nie, maar ook op die argitektoniese aantreklikheid van die geheel. In hierdie verband moet, so vervolg hy, by die daarstelling van'n permanente kamp, waar een aantal zonen des lands zullen worden gehuisvest, om zich in de militaire dienst te bekwamen, veral aandag geskenk word aan die wenslikheid dat hulle die kamp as hul tuiste moet beskou.

e. Dit is militêre tradisie dat offisiere by 'n kamp woon. Olı hierdie rede het hy offisierswonings buite die kamp in gedagte en stel hy voor dat 'n terrein tussen die kampmuur en Maréstraat vir dié doel aangewend word.

f. Deur die kampgeboue op 'n bepaalde wyse op die terrein te plaas, ontstaan 'n drietal pleine met besondere bestemmings t.w. die voorplein, die drilplein en die stalplein. Eersgenoemde plein word omring deur die kampingang en geboue vir administrasie, kontrole, voeding- en huisvestingsdoeleindes. Die drilplein, m.a.w. die middelste, is geleë tussen die beoogde kaserne, die stalle, die kanonhuise en die magasyne en vir die hou van plaaslike oefeninge, die dril van rekrute en die gee van rylesse bedoel, terwyl die stalplein omring is deur stalgeboue en as binneplaas vir werksaamhede dien wat in verband met perde en stalle staan.

g. Die ommuurde kamp moet oor twee poorte beskik, naamlik een vir die hoofwag (geleë aan die voorplein, teenoor Scheidingstraat) en die ander by die drilterrein. Laasgenoemde sal gebruik word vir in- en uitgaan van geskut, diensvoertuie, perde, die uitruk van afdelings e.d.m.'

h. Links en regs, agter die hoofwag, moet twee blokke, elkeen van twec wonings en met die voorgewels na die hoofplein gerig, gebou word. Ander geboue aan dié plein is 'n woning vir die hoef- en wapensmid, die smidswinkel, die skrynwerkerswerkplaas en die woning van die A.O.

j. Midde op die voorplein moet 'n administrasiegebou, waarin 'n lees- en konferensiesaal en geboue vir die Afdeling Veldtelegrafie, verrys. Aan die agterkant van dieselfde plein, teenoor die hoofingang, moet 'n dubbelverdieping kaserne vir 200 artilleriste gebou word.

k. Aan die sykant van die voorplein word 'n kombuisgebou en reg teenoor hierdie gebou, 'n konversasiegebou vir ontspanningdoeleindes beoog.

1. Agter die kaserne, aan weerskante van die drilplein, word kanon- en waenhuise $\left(40^{\prime} \times 150^{\prime}\right)$ met langsaan, aan die een kant 'n magasyn en aan die ander kant 'n ammunisiemagasyn beoog, terwyl op die terrein ritmeesterskantoor, m.a.w. 'n beheerpos, moet verrys.

m. Agter die drilplein moet 4 stalgeboue, bereken vir 200 perde vir manskappe, met aan die een kant ' $n$ stal vir 28 offisiersperde en aan die ander kant 'n hospitaalstal vir 12 perde, gebou word, terwyl in die middel van elke stalgebou tuiekamers en trappe na die voersolders aangebring moet word.

n. Van Rijsse het verder beklemtoon dat die koste vir die bou van een zoo belangrijke en voor's lands veiligheid zoo noodzakelijke stichting. . . het verkrijgen van een modelinrichting nie in die pad mag staan nie.

Sy begroting het soos volg daar uitgesien: Hoofwag: $£ 7,000$ (R14,000), wonings vir onderoffisiere ( 2 blokke): $£ 2,000$ (R4,000); 'n woning vir die hoef- en wapensmid: $£ 1,000$ (R2,000), die administrasiegebou: $£ 4.000$ (R8,000), 'n manskappe-kaserne: $£ 12,000$ (R24,000), 'n kombuisgebou: $£ 2,000$ (R4,000), 'n ontspanningsgebou: $£ 2,000$ (R4,000), 'n kanonhuis: $£ 2,200$ ( $R 4,400)$, 'n waenhuis $£ 2,200$ (R4,400), 'n ammunisiemagasyn: $£ 1,800(\mathrm{R} 3,600)$, 'n ritmeesterskantoor: $£ 300$ (R600), perdestalle (manskappe): $£ 9,000$ (R18,000). perdestalle (offisiere): $£ 1,500$ (R3,000), hospitaalstalle: $£ 1.500$ (R3,000), latrines e.d.m.: $£ 500$ (R1,000), afsluitmure (ringmuur): 


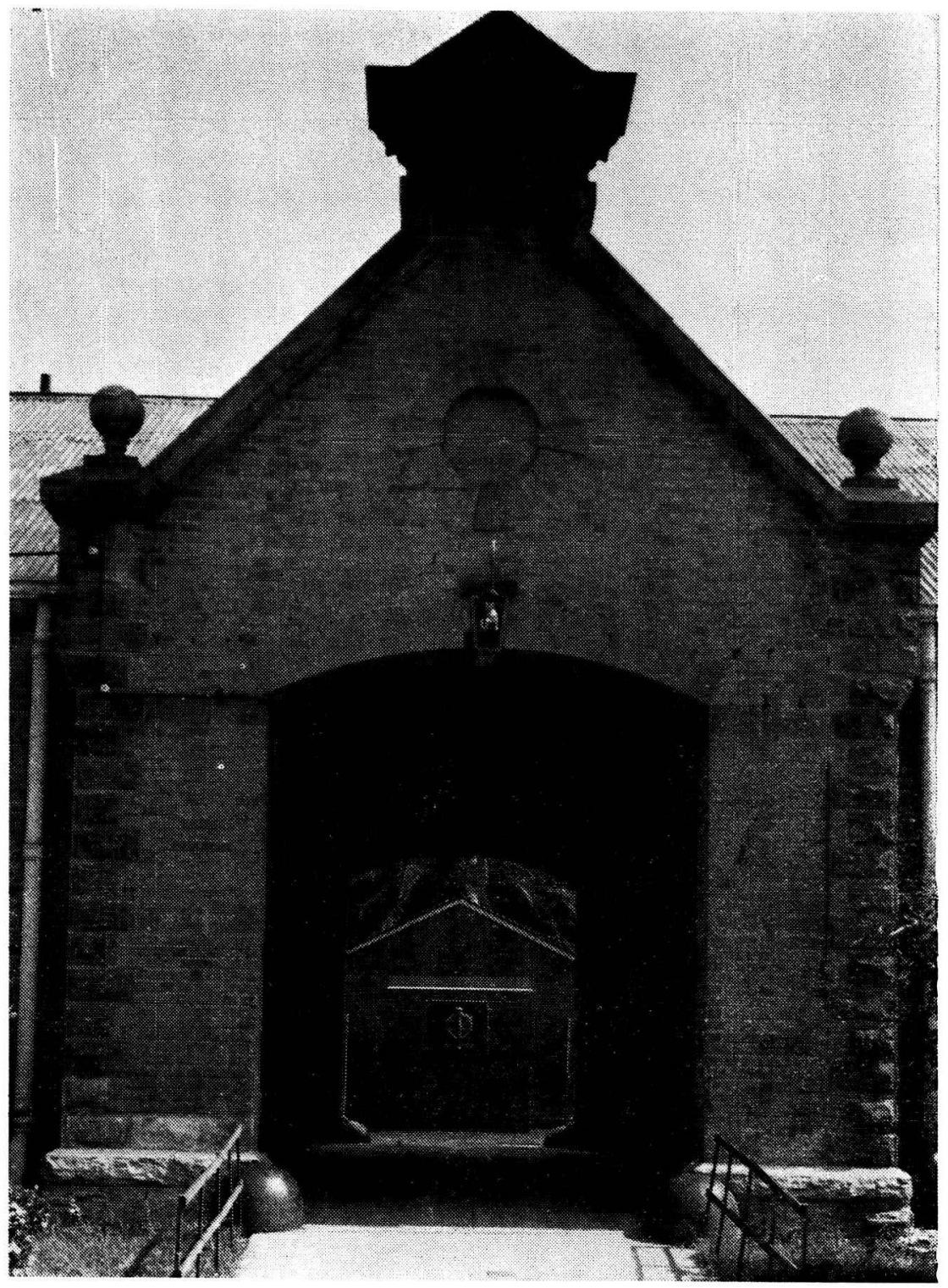

Die poort van een van die voormalige kanon- en waenhuise van die Korps Staatsartillerie, Potgieterstraat, Pretoria. $O p$ die agtergrond ' $n$ geboutije wat later op die binneplaas gebou is.

Foto: Militêr-Historiese en Argivale Dienste.

The gateway of one of the former gun and wagon sheds of the Artillery Corps, Potgieter Street, Pretoria. In the background a building erected in the courtyard at a later stage.

Photograph: Military Historical and Archival Services. 
$£ 15,400$ (R30,800), pleinmure e.d.m.: $£ 3,500$ (R7,000), 'n woning vir die korpskommandant: $£ 2,000(\mathrm{R} 4,000)$, 'n woning vir die kaptein-administrateur: $£ 1,500$ ( $R 3,000)$, wonings vir 4 getroude luitenante: $£ 4,000(R 8,000)$, woonhuise vir ongetroude luitenante: $£ 1,500(\mathrm{R} 3,000)$, ' $\mathrm{n}$ woonhuis vir die magasynmeester: $£ 700$ (R1,400), grondwerk e.d.m.: $£ 1,600(\mathrm{R} 3,290)$. Totaal: $£ 70,000$ (R140,000).

Ten slotte het Van Rijsse voorgestel dat die geboue in natuur- en baksteen opgetrek word, op 'n klipfondering moet rus en dat die werksaamhede ooreenkomstig bestaande behoeftes uitgevoer moet word. Rekening moet ook gehou word met die bestaande kampgeboue wat, na gelang die vordering van die werksaamhede, geleidelik afgebreek moet word.

\section{Huisvestingsvraagstukke}

Aanvanklik het die bouplanne van Van Rijsse bly lê. In Augustus 1894 het die Wet en Regulaties voor het Korps Rijdende Artillerie der Zuid-Afrikaansche Republiek (wet no. 15, 1894) waarin o.m. voorsiening gemaak is vir 'n eenheid van 154 offisiere en manskappe, in werking getree $^{13}$.

Op 11 Maart 1895 het die waarn. kaptein R.A. aan genl. P. J. Joubert berig dat tente op die kampterrein opgeslaan is om manskappe te huisves en dat 'n groot aantal artilleriste siek was. In dieselfde skrywe is die volgende versugting geslaak: Indien wij van soldaten gehoorzaamheid en plichtsbetrachting eischen, dienen wij te zorgen dat ze ook behoorlijk verzorg worden ${ }^{14}$.

Twee dae later teken waarn. kommandant Bosman by hierdie skrywe aan dat, as gevolg van 'n ware luiseplaag, manskappe in tente en twee ou kommandowaens slaap.

Namens die kommandant-generaal teken sekretaris F. C. Stiemens kort daarna op die betrokke lêer aan: Waak en zorg dat de manschappen behoorlijk verzorgd worden. Op hierdie instruksies lewer lt.-kol. H. P. N. Pretorius soos volg repliek: Comdt. Genl. onder bestaande omstandigheden is dat voor mij onmogenlijk . . .

\section{Die stalgeboue, die kanon- en waenhuise}

Die huidige, voormalige stalgeboue op die terrein van die Verdedigingshoofkwartier, agter die reeds genoemde drilplein, bestaan uit 2 gedeeltes, t.w. die 6 geboue wat in die vorm van 'n langwerpige reghoek geplaas is en die 2 U-vormiges wat jonger is.

Op 20 Augustus 1895 het, na aanleiding van tender no. 768, die tenderkommissie van die Zuid-Afrikaansche Republiek die tender van bou-aannemer J. J. Kirkness (Pretoria) ten bedrae van $£ 33,750(\mathrm{R} 67,500)$ aanvaar, terwyl die tender vir laasgenoemdes kragtens Uitvoerende Raadsbesluit art. 486, van 10 Junie 1896, aan dieselfde kontrakteur teen 'n koste van $£ 45,450(R 90,000)$ toegewys is ${ }^{\prime 5}$.

Hierdie geboue, waarvan veral die U-vormiges tot vandag toe indruk maak deur die afmetings (totale lengte ruim $217^{\prime}$, vleuels elkeen ruim $141^{\prime}$ ) en die tuiekamers (twee verdiepings) herinner nie alleen aan die belangrike rol wat die perd in ons militêre geskiedenis gespeel het nie, maar ook aan die deeglikheid waarmee ons voorouers in die verlede beplan en hul werksaamhede uitgevoer het.

Nog 'n aspek is dat die oudste geboue voor en die ander na die Jameson-inval gebou is. Dit was, soos bekend, laasgenoemde voorval wat die Transvaalse Regering in Januarie en Februarie 1896 laat besluit het om o.m. tot uitbreiding van die bestaande Artilleriekorps tot 400 man oor te gaan, 'n besluit wat sy invloed op die bebouing van die Pretoriase kampterrein, soos o.m. in die bou van die U-vormige stalgeboue weerspieël is, laat geld het.

Op 2 Oktober 1895 het die Departement van Openbare Werke tekeninge met betrekking tot 'n tweetal kanon- en waenhuise gereed gekry. Die spesifikasies is op 4 November van dieselfde jaar voltooi, tenders kon tot 12 Desember 1895 aan die ouditeur-generaal gestuur word en op 22 Januarie 1896 het die Uitvoerende $\mathrm{Raad}$ besluit om in plaas van 2 onverwyld 4 kanon- en waenhuise in die Artilleriekamp te laat bou waarvan die totale boukoste hoogstens $£ 40,000$ (R80,000) mag wees ${ }^{16}$. 


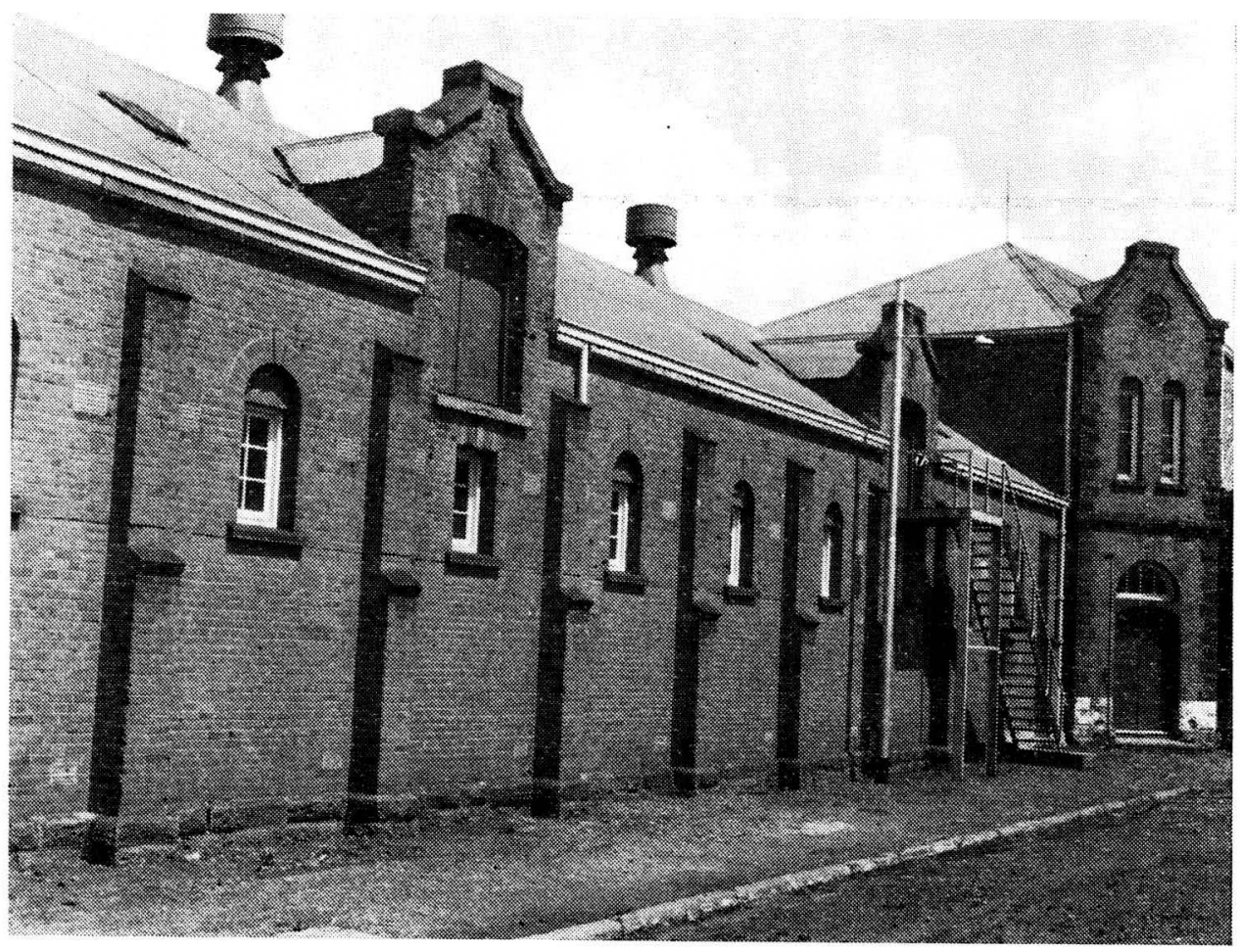

' $n$ Gedeelte van een van die groot stalgeboue met, as hoogste gedeelte, die eertydse tuiekamer.

Foto: Militêr-Historiese en Argivale Dienste.

A portion of one of the large stables with, as highest part, the former harness room.

Photograph: Military Historical and Archival Services. 


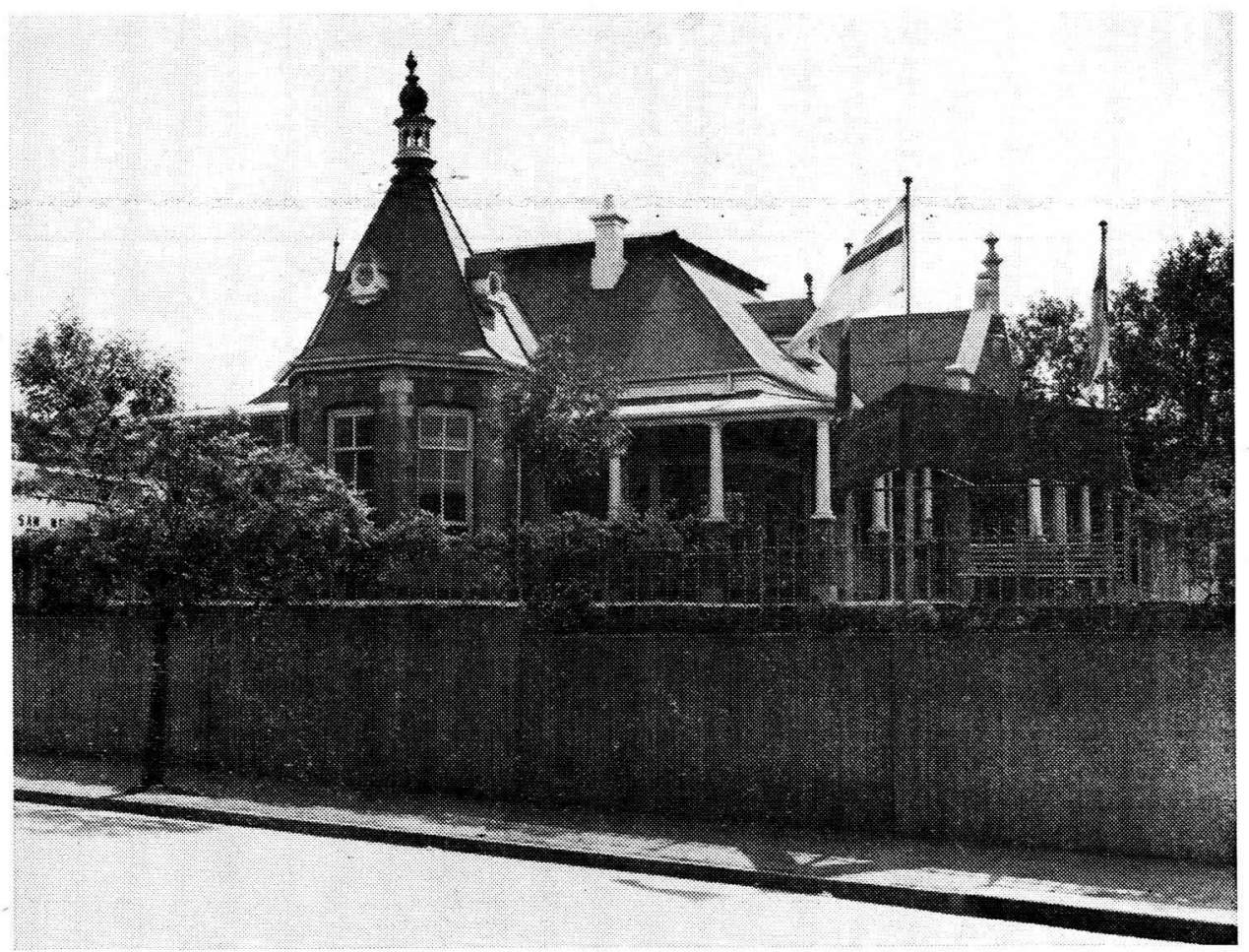

Hierdie gebou, wat tans as werwingskantoor S.A.W. in gebruik is, was lt.-kol. S. P. E. Trichardt, kommandant van die Korps Staatsartillerie, se ampswoning. Foto: Militêr-Historiese en Argivale Dienste.

This building, at present used as the S.A.D.F. Recruiting Office, was the official residence of lt.-col. S. P. E. Trichardt, Commandant of the State Artillery Corps. Photograph: Military Historical and Archival Services. 
Terwyl vir die bou van die U-vormige stalgeboue 12 maande toegestaan is, moes die 4 kanon- en waenhuise 6 maande na anvaarding van die tender opgelewer word.

In die spesifikasie Bestek en Voorwaarden wegens het bouwen van twee kanonen wagenhuizen voor het Corps Staats-Artillerie te Pretoria is o.m. vermeld dat die voorgewels van die 2 geboue $o p$ 192'6" van het hart van genoemd drilplein, $O P$ onderlingen afstand van 40' opgetrek moet word zodat het hart der doorgang tusschen deze gebouwen tegenover het hart der Parkstraat komt te liggen.

Die lengte en breedte van die kanon- en waenhuise is op $156^{\prime}$ en $140^{\prime}$ bepaal, terwyl die afmetings van die binneplaas op $99^{\prime} \times 78^{\prime} 3^{\prime \prime}$ vasgestel is.

Baksteen, graniet en sandsteen is as boumateriaal voorgeskrywe, terwyl die hoofingang van die geboue deur smeedyster poorthekke afgesluit moes word.

Dit is veral die ingangspoorte tot hierdie geboue wat, deur die spaarsame toepassing van sandsteen en sandsteen-ornamente, ons sterk aan die NederlandsVlaamse neo-Renaissance boukuns van die laat negentiger jare van die vorige een laat herinner, t.w. soos dié besondere boustyl deur die ontwerper vertolk is.

Veelvuldiger toegepas in die Artilleriekaserne en die offisierswonings in Artillerieweg, die kerkgebou van die Gereformeerde gemeente regoor die Presidentswoning in Kerkstraat en die Staatsmodelskool, het Pretoria gedurende die laaste jare van die 19de eeu sowel op die gebied van die militêre- as die kerklike-en burgerlike boukuns 'n aantal belangrike geboue verkry wat, kunshistories en argitektonies beskou, uniek in ons land is ${ }^{17}$.

Op 7 Januarie 1897 is die kommandant-generaal van die oordrag, deur bou-aannemer J. J. Kirkness, van die kanon- en waenhuise aan die suidekant van die drilplein, verwittig ${ }^{13}$.

In die loop van dieselfde jaar het die U-vormige stalgeboue, waarin 268 perde ondergebring kon word, gereed gekom, terwyl ook in die loop van dieselfde jaar besluit is om die ruimte tussen genoemde kanon- en waenhuise van 'n dak te voorsien ${ }^{19}$.

\section{Die offisiers- en onderoffisierswonings langsaan die Artilleriekamp}

Ooreenkomstig die gedagtes wat in 1894 deur argitek K. Van Rijsse m.b.t. die terrein uitgespreek is waarop offisiers- en onderoffisierswonings vir die Artilleriekorps gebou moet word, t.w. aan die noordekant van die kamp, het op 18 Desember 1895 die tekeninge vir die beoogde 15 woonhuise gereed gekom.

Op 25 Februarie 1896 was die Bestek en Voorwaarden wegens het bouwen van Officiers- en Onderofficierswoningen met annexe werken voor het Corps Staatsartillerie te Pretoria gereed ${ }^{20}$.

Bogenoemde wonings is, wat grootte en voorkoms betref, in die volgende tipes verdeel:

a. Die ampswoning van die Korpskommandant, op die hoek van Potgieterstraat, $53^{\prime} 10^{\prime \prime} \times 52^{\prime} 4^{\prime \prime}$.

b. Twee kapteinswonings, $46^{\prime} 10^{\prime \prime} \times 57^{\prime} 4^{\prime \prime}$.

c. Ses luitenantswonings, $42^{\prime} 10^{\prime \prime} \times 57^{\prime} 4^{\prime \prime}$.

d. Ses onderoffisierswonings, $37^{\prime} 4^{\prime \prime} \times 47^{\prime} 7^{\prime \prime}$.

Behalwe dat hierdie ampswonings van verskillende grootte is, is daar ook t.o.v. plafonhoogte, die hoogte en breedte van die gange en voordeurkosyne e.d.m. verskillende afmetings voorgeskrywe. Die laasgenoemde tipe het nie oor een bergplaats voor een spider en 'n studeerkamer beskik nie.

Die kommandantswoning is tydens die Republikeinse tydperk deur lt.-kol. S. P. E. Trichardt bewoon en trek tot vandag toe nog die aandag deur sy sierlike torinkie, sy Duitse dakhekkies, sy binnebetimmering, sy vuurherde e.d.m.

Gesien as 'n reeks is al hierdie wonings, wat argitektonies 'n sterk neo-Renaissanceinslag vertoon, besonder indrukwekkend en, militêr-histories gesien. waardevolle erfenisse uit 'n trotse verlede.

Op 2 Mei 1896 het die Uitvoerende Raad besluit om die tender van kontrakteur J. J. Kirkness ten bedrae van $£ 31,340(\mathrm{R} 62,680)$ te aanvaar. Soos in die verlede het die uitvoering by die hoof van die Departement van Openbare Werke berus. Binne 15 maande moes die projek voltooi wees ${ }^{21}$. 


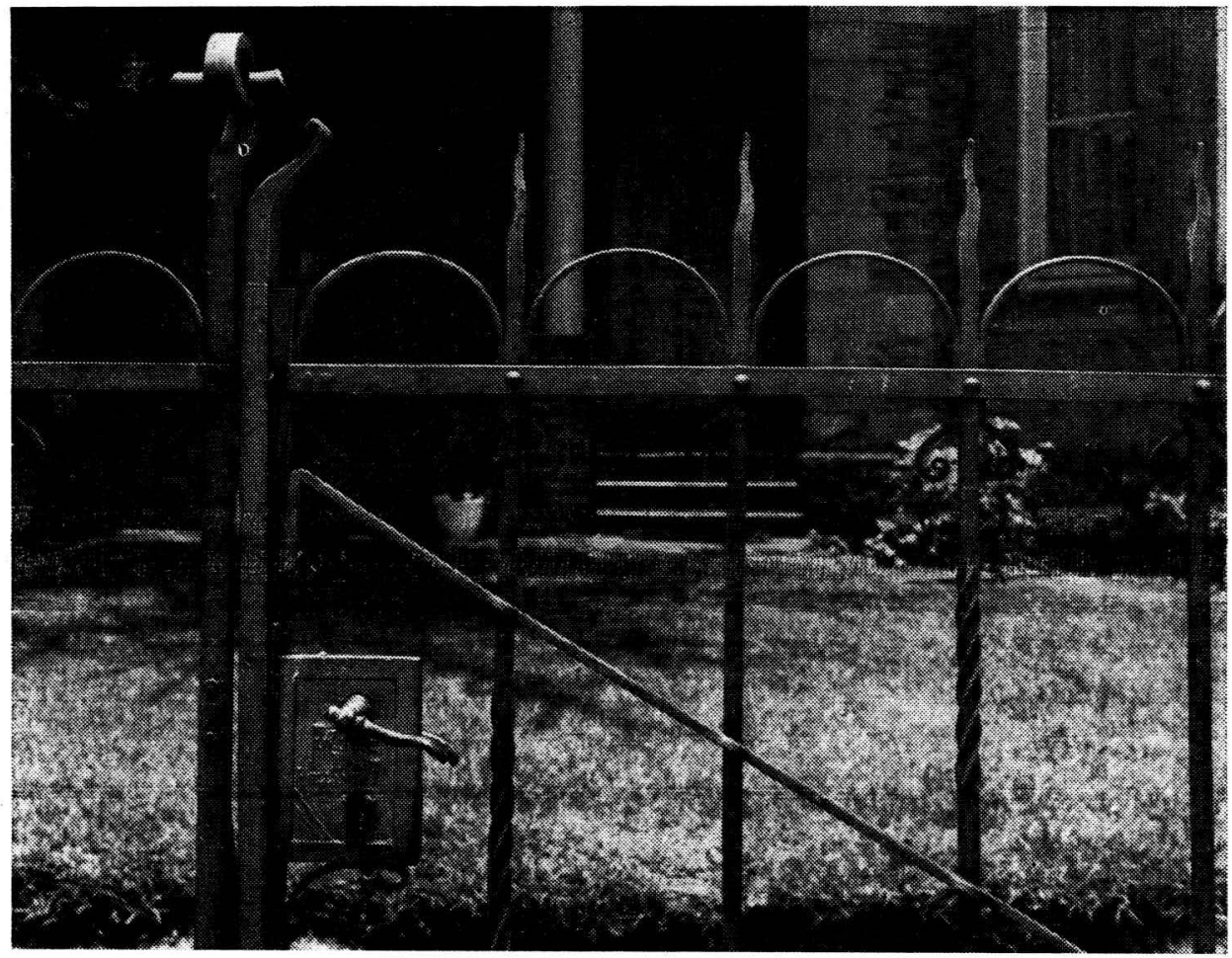

Nie elke verbyganger bestee aandag aan die outydse hekwerk voor die voormalige offisierswonings van die Korps Staatsartillerie nie.

Foto: Militêr-Historiese en Argivale Dienste.

Not every passer-by pays attention to the old-fashioned gatework in front of the former officers' residences of the State Artillery Corps.

Photograph: Military Historical and Archival Services. 


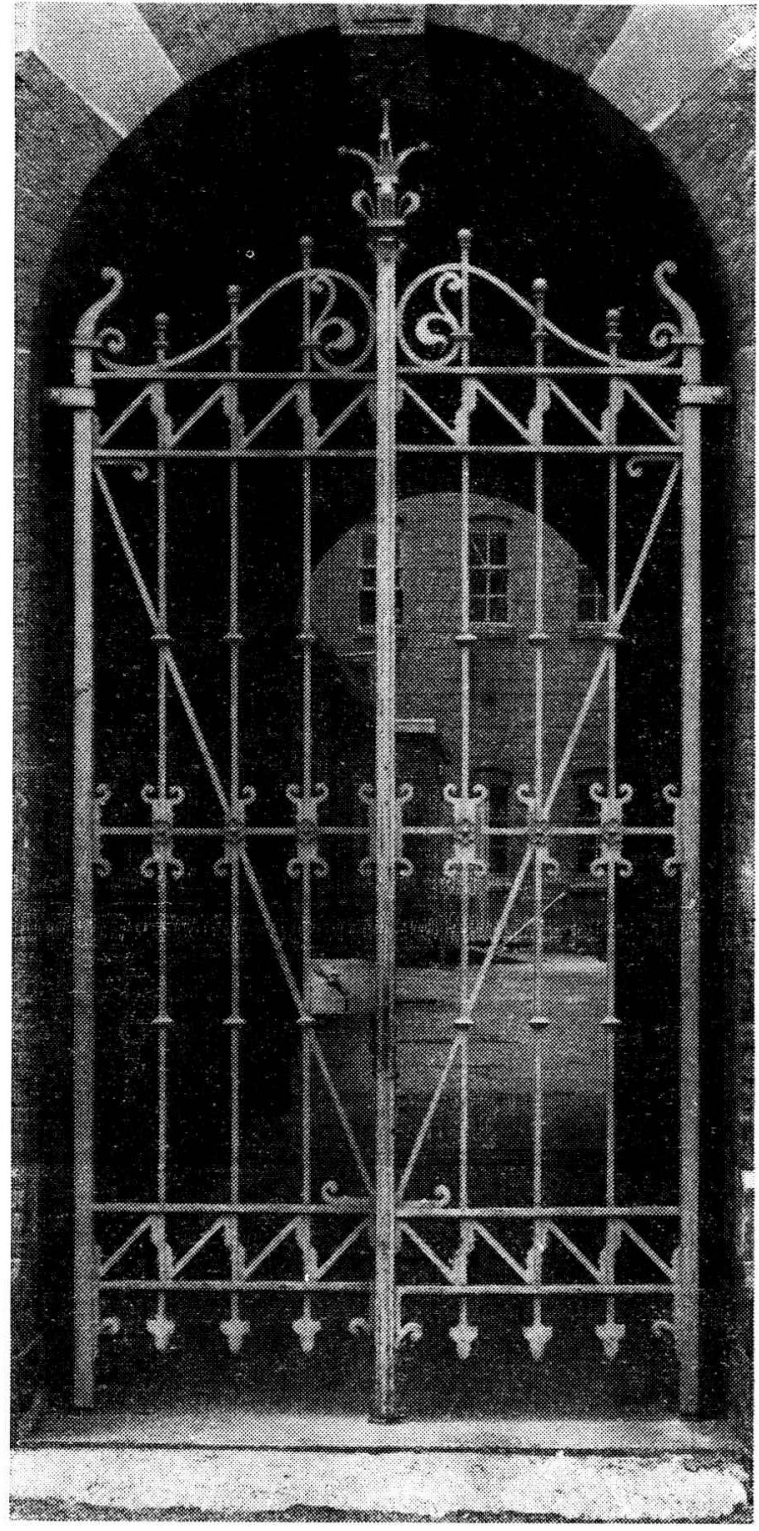

Pragtige outydse smeedyster hekke sluit een van die binneplase van die voormalige kaserne van die Korps Staatsartillerie af.

Foto: Militêr-Historiese en Argivale Dienste.

Beautiful wrought iron gates enclose one of the court yards of the former barracks of the State Artillery Corps.

Photograph: Military Historical and Archival Services. 


\section{Die Staatsartillerie-kaserne}

Op 8 Julie 1896 het Wierda aan genl. P. J. Joubert berig dat die tender vir die beoogde Staatsartillerie-kaserne deur die Uitvoerende Raad goedgekeur en dat die daaruit voortvloeiende ooreenkoms ten bedrae van $£ 58,250$ (R116.500) tussen die Regering en die Societa Italiana di Costruzione onderteken is. In dieselfde skrywe is die kommandant-generaal daarvan verwittig dat die bouterrein in die Artilleriekamp binnekort aangewys en die bestaande kaserne ontruim en gesloop word ${ }^{22}$.

Aan hierdie mededeling het die vervaardigers van die vier benodigde boutekeninge, wat op 20 Februarie 1896 gereed gekom het, en die opstel van die Bestek en Voorwaarden wegens het bouwen van een manschappenkazerne met annexe werken voor het Corps Staats-Artillerie te Pretoria, gedateer 1 April 1896, vorafgegaan. In laasgenoemde dokument is, aangaande die plasing van die kaserne in die Artilleriekamp, verklaar dat het hart van het gebouw komt te liggen in de hartlijn van hei daarachter gelegen drilplein (zijnde het hart van Scheidingstraat), en met de achtergevel 200 voet uit de verlengde hartlijn der Parkstraat.

Die lengte van die voor-, agter- en sygewels in onderskeidelik op $314^{\prime}$ en $106^{\prime} 8^{\prime \prime}$ vasgestel, terwyl die lengte en breedte van die binneplase op 113'37" bepaal is. Dic hoogste punt van die gebou, bokant die toringkoepel, is op 82'6" vasgestel en die kaserne sou uit twee verdiepings en 'n solder bestaan.

Binne 18 maande moes hierdie indrukwekkende kaserne, met sy sierlike middefront, sy hoekpaviljoene en sy 16 groot slaapsale vir manskappe, kamers vir onderoffisiere, was- en badkamers voltooi wees.

Op 21 Julie 1896 het die kontrakteur toestemming gevra om tydelike geboue vir sy werknemers naby die bouterrein te mag oprig, om bakstene binne die kampongheining te vervaardig en om 'n tremspoor aan te lê om klip uit die rant aan die einde van Potgieterstraat te kan haal ${ }^{23}$.

Met hierdie versoeke het die bou van die waarlik indrukwekkende oudste gedeelte van die Verdedigingshoofkwartier aan Potgieterstraat begin. Dit dien, voordat meer besonderhede aangaande die boubedrywighede verstrek word, nog opgemerk te word dat met die oog op moontlike brandgevaar, sindelikheid en higiëne die balklae, vloere en trappe in die gebou van yster en klip vervaardig is $^{24}$.

Met die grawe van die fonderings van die kaserne is tydens die eerste week van November 1896 begin, nadat hieraan 'n aantal voorbereidende werksaamhede soos die bou van die kontrakteur se kantoor op die terrein in die week van 20-25 Julie voorafgegaan het ${ }^{25}$.

Gedurende die daaropvolgende 2 weke is die ringmuur om die kamp verwyder en 'n gat in die ou kanonhuis (afdak) gebreek om die tremspoor hierdcur te lê.

Van 10-15 Augustus is aan die geboutjie van die opsigter gewerk en draagbare spoorgedeeltes vir die vervoer van uit te grawe grond en die aanvoer van klip gelê. Daar is terselfdertyd met die oprigting van masjinerie en die aanlê van kalkopslagplekke begin terwyl ook 'n masjien met 'n ketel vir die voorbereiding van messelkalk opgestel is.

In die loop van die werksweek van 24-29 Augustus is begin om grond uit te grawe en verder gegaan om die tremspoor te lê, terwyl tussen 21 en 26 September die eerste vyf vragte klip aangevoer is.

Van 5-10 Oktober 1896 is meer messelsand gemaal en verdere hoeveelhede klip aangevoer. Terselfdertyd is begin om die ou kaserne af te breek. Laasgenoemde werksaamhede was tussen 26 en 31 Oktober nog aan die gang.

Terwyl die eerste fonderings gedurende die eerste week van November gegrawe is, is 'n gedeelte van die terrein in die rigting van die drilplein verder afgegrawe. Tussen 4 en 9 Januarie 1897 is met die messel van die fondering begin en van 17 tot 23 Januarie 1897 is dié klippe van die fondering wat bo op die grond sou gelê word, in gereedheid gebring. Sand en sandsteen in aangevoer en gedurende die week van 25-30 Januarie is begin om die fondering van die binnemure te lê.

In Maart 1897 het die werk 'n geruime tyd stilgelê. Vermoedelik was dit ook toe te skrywe aan 'n tekort aan bakstene, maar allereers aan die feit dat die oorspronklike bouaannemer sy verpligtings aan die Franco Italian Building Company oorgedra het. Hierdie maatskappy is, soos dit wil voorkom, geldelik deur die Banque Française de l' Afrique du Sud gesteun en het die bou van die kaserne voltooi ${ }^{20}$. 


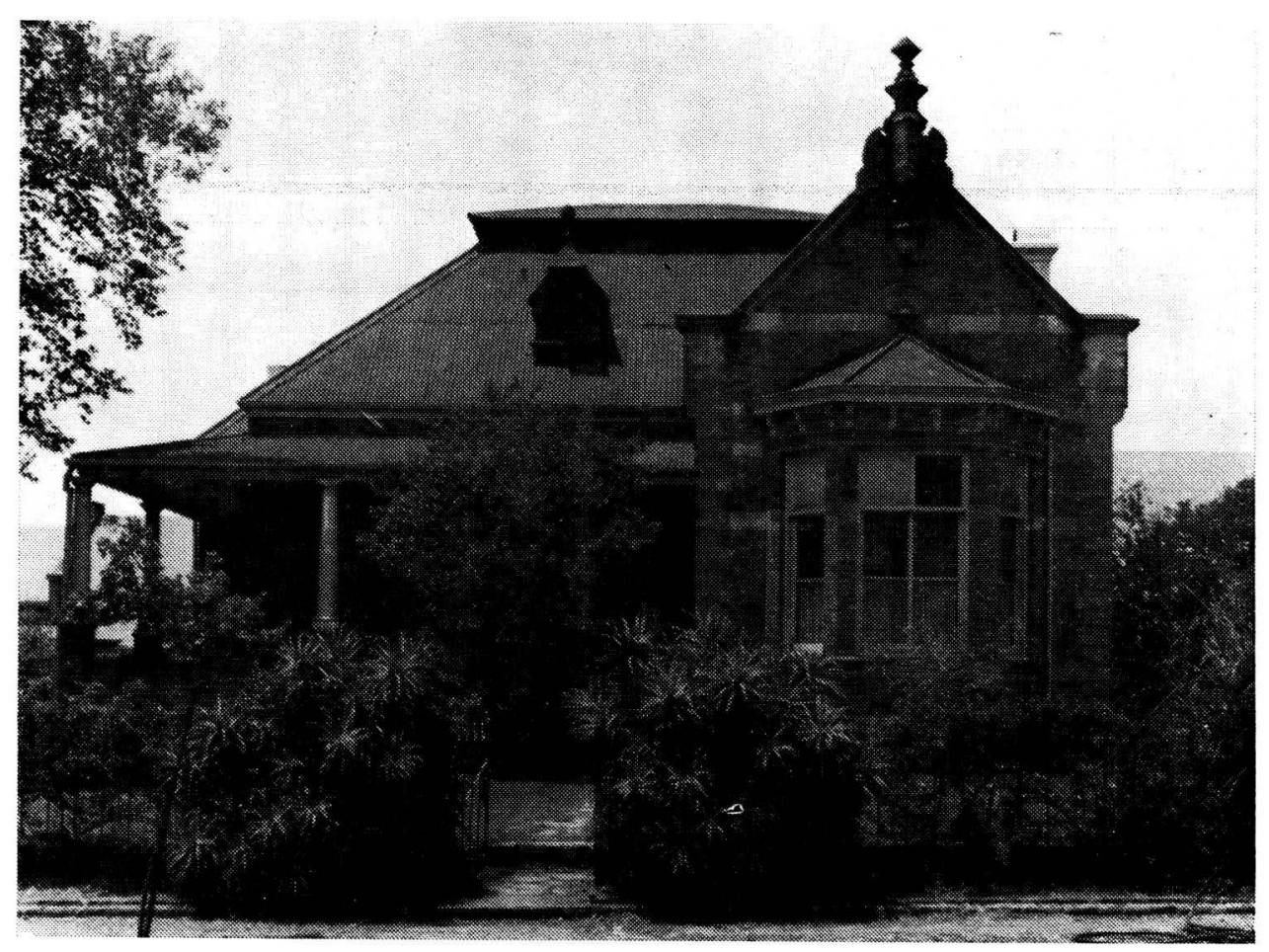

Een van die voormalige offisierswonings, Korps Staatsartillerie, Pretoria.

Foto: Militêr-Historiese en Argivale Dienste.

One of the former officer's residences, State Artillery Corps, Pretoria.

Photograph: Military Historical and Archival Services. 
Op 15 Maart 1897 is 50,000 bakstene aangevoer en daarna is voortgegaan om die binnemure van die kaserne te messel. Deurkosyne is opgestel en op dié tydstip was 2 smede, 6 klipkappers (graniet), 7 klipkappers (sandsteen), 1 skrynwerker, 18 messelaars, 10 blanke handlangers en 14 Bantoes by die werk betrokke.

Gedurende die werksweek van 26 April-1 Mei 1897 is o.m. met die messel van die voor-, agter- en sygewels begin en is sandsteen opgestel.

Kort daarna het daar weer 'n ernstige baksteentekort ontstaan en eers na die eerste helfte van Junie is met die aanvoer van Daspoortse baksteen begin. Op 24 Julie was die messelaars orals feitlik tot die bokant van die raam-kosyne van die eerste verdieping van die kaserne gevorder, terwyl aan die begin van Augustus werkers nog bedrywig was om die plein voor die gebou met grond op te vul.

In die verslag oor die tydperk 9-14 Augustus is vir die eerste maal van twee Italiaanse messelaarsbase gewag gemaak. Op 21 Augustus was die messelwerk tot aan die onderkant van die ysterbalke gevorder waarop die gewelwe van die eerste verdieping sou rus.

Tussen 25 Oktober en 6 November 1897 is begin om die tweede ysterbalklaag, t.w. tussen die tweede verdieping en die solder, te lê en op dié tydstip was 30 messelaars, 11 skrynwerkers, 40 klipkappers, 15 handlangers en 150 Bantoes op die bouterrein bedrywig.

Tussen 8 en 13 November is 'n gedeelte van 'n gewelf, wat van Transvaalse sement vervaardig was, t.w. een vierkante jaart, onder 'n druk van $2,240 \mathrm{~kg}$ geplaas en in die loop van dieselfde week is 100,000 bakstene op die terrein afgelewer, terwyl daar tussen 22 en 27 November met die messel van die hoekpaviljoene begin is.

In Desember het die drilplein, met uitsondering van die lê van ouklip, gereed gekom en in Januarie 1898 het die werksaamhede met betrekking tot die plein voor die kaserne ten einde geloop.

Tussen 21 en 26 Maart 1898 is die asfaltvloere in die 4 groot slaapsale van die eerste verdieping en in die wapenkamers aan die voorkant van die gebou gelê.

Teen die einde van Mei 1898, die asfaltvloere het inmiddels gereed gekom, is bome voor die kaserne geplant en in die verslag oor die tydperk 5-9 Junie 1898 is vermeld dat die nuwe kaserne feitlik voltooi was en twee weke gelede in gebruik geneem is.

In die loop van die week van 12-17 September 1898 is die kaserne aan die Regering oorgedra. Op dié typstip was die vasgestelde boutyd reeds verstreke en ten opsigte van die tydperk na 8 Julie 1898 is vir elke dag $£ 10$ (R20) van die kontrakprys afgetrek terwyl $£ 400(\mathrm{R} 800)$ in mindering gebring is omdat die toring se uurwerk nie gelewer was nie.

Op 25 Maart 1899, m.a.w. nadat die voorgeskrewe onderhoudstydperk verstreke was, is die laaste gedeelte van die boukoste an die kontrakteur betaal ${ }^{27}$.

Eindelik het, soos in die departementele verslag van Openbare Werke vermeld is, dit forsche gebouw van twee verdiepingen, met vier verhoogde hoekpaviljoens en rijzigen middenkoepel ${ }^{8}$ gereed gekom en in sy verslag oor 1898 kon die kommandant-generaal met trots getuig:

De Zuid-Afrikaansche Republiek is nu in het bezit van een kamp, zooals bijna nergens ter wereld bestaat . . . ${ }^{29}$.

10 Die verslag van die Departement van Openbare Werke (1896) aan die Volksraad voorgelê

Op 25 Mei 1897 is bogenoemde verslag in die Eerste Volksraad ter tafel gelể ${ }^{32}$. Nie alleen was, met betrekking tot Pretoria, die nuwe kaserne in aanbou nie, maar terselfdertyd was die volgende geboue op en naby aan die Artillerieterrein in aanbou of voltooi: 4 kanon- en waenhuise, 8 perdestalle en 15 offisiers- en onderoffisierswonings. Hulp- en tydelike geboue het verrys en bestaandes is gesloop en terselfdertyd is nog beoog om 'n ryskool, 'n ontspanningsgebou, 'n masjiengebou, 'n kombuisgebou en 'n magasyn met 'n waenhuis vir die Afdeling Veldtelegrafie te bou. 
Terwyl bogenoemde militêre geboue gereed gekom het, in uitvoering was of vir die toekoms beoog is, is sowel nuwe geboue van die Staatsdrukkery as die Staatsmodelskool in gebruik geneem, terwyl aan Kerkplein die Paleis van Justisie begin verrys het.

Met betrekking tot die geboue in en by die Artilleriekamp is in 1896 die volgende afgeronde bedrae aan kontrakteurs betaal:

\begin{tabular}{|c|c|}
\hline $\begin{array}{l}\text { J. Kirkness - vir } 6 \text { perc } \\
\text { J. Kirkness - vir } 2 \mathrm{U} \\
\text { J. Kirkness - vir } 2 \mathrm{ka} \\
\text { J. Kirkness - vir } 15 \mathrm{o} \\
\text { J. Kirkness - vir 'n t }\end{array}$ & $\left.\begin{array}{r}£ 23,499 \\
\ldots 4,545 \\
\ldots . . . \\
\ldots 14,000 \\
\ldots 15,670 \\
\ldots \\
£ 1,834\end{array}\right\}$ \\
\hline
\end{tabular}

Die totale begroting van bogenoemde departement vir 1896 het $£ 535,089$ $(\mathrm{R} 1,070,178)$ bedra, terwyl in werklikheid ruim $£ 414,760$ ( $R 829,520)$ uitgegee is waarvan ruim $£ 233,728$ ( $\mathrm{R} 467,456)$ aan die bou van openbare geboue bestee is.

Dat die hele begrote bedrag nie uitgegee is nie, was hoofsaaklik toe te skrywe aan die uitbreek van runderpes waardeur die vervoer lamgelê is ${ }^{31}$.

Tydens die Volksraadsbedat oor die goewermentsgeboue in Pretoria het verskeie lede hul misnoeë oor die weelderige wyse uitgespreek waarop die stalle gebou en ingerig is, terwyl Volksraadslid A. D. W. Wolmarans van mening was dat, indien groot bouwerke opgerig word, eers die goedkeuring van die Volksraad met betrekking tot die beoogde uitgawes verkry moet word ${ }^{32}$.

$\mathrm{Na}$ aanleiding van hierdie en ander debatspunte wat te berde gebring is, het die Raad op 3 Junie 1897 besluit om die verslag van die Departement van Openbare Werke vir kennisgewing aan te neem. Verder is o.m. besluit om, met die oog op die heersende finansiële toestand, die Regering op te dra de niet dringend noodzakelijke werken niet te doen uitvoeren en verder uit te voeren werken, zoo min mogelijk kostbaar te doen bouwen. . . .33.

Hierdie besluit het, soos aangetoon sal word, o.m. ook die verdere bebouing van die Artilleriekamp sterk beinvloed. Voordat verder op hierdie aspek ingegaan word, moet daar nog melding gemaak word van 'n tweetal geboue waarvan die oprigting in die loop van 1896 deur die Uitvoerende Raad goedgekeur is.

11 Die magasyne en waenhuise van die Afdeling Veldtelegrafie, die masijiengebou

Op die noordoostelike hoek van die kampterrein en wel zoodat de eindgevel naar de Potgieterstraat komt te staan, aldus die Bestek en Voorwaarden van 1 April 1896, is in die loop van dieselfde jaar 'n aantal magasyne en waenhuise ten behoewe van die Afdeling Veldtelegrafie van die Staatsartillerie gebou.

Die tekening van 17 Maart 1896 vertoon 'n gebou van $348^{\prime} 3$ " lengte met ' $n$ breedte van $23^{\prime} 6^{\prime \prime}$ wat onderverdeel is in 3 magasyne en 3 waenhuise met, aan die westekant, 'n oop kookgeleentheid.

Die oorspronklike endgewel, aan Potgieterstraat, wat tans ' $n$ deel van die gelyknamige poskantoor vorm, is met 'n sandsteenhekwerk en -hoekstukke versier. Die boukoste van hierdie gebou het $£ 7,977$ ( $\mathrm{R} 15,954)$ bedra en die geheel is deur die Te Groen-broers uitgevoer ${ }^{34}$.

Die masjiengebou is aan die noordekant van die huidige voorplein en suid van bogenoemde gebou opgerig en beskrywe in die Bestek en voorwaarden wegens het bouwen van een machine-gebouw e.a., voor het Corps Staatsartillerie te Pretoria wat van 25 Januarie 1897 dateer en gebaseer is op 'n drietal tekeninge van 31 Desember van die voorafgaande jaar ${ }^{35}$. Op 24 Maart 1896 het die Uitvoerende Raad besluit om die tender van die Te Groen-broers van $£ 11,971(\mathrm{R} 23,942)$ te aanvaar ${ }^{36}$. Die lengte van die masjiengebou is op $100^{\prime}$ en die breedte op 56 $6^{\prime} 6^{\prime \prime}$ bepaal. Daar is ook melding gemaak vir 'n ketelhuis met 2 stoomketels, 'n opslagplek vir steenkool, 'n masjienkamer, batterykamers en 'n skoorsteen van 100 voet. Die gebou moes binne 12 maande gereed kom en die opstel van die ketels sowel as die bou van die skoorsteen is aan J. Mundt opgedra ${ }^{37}$.

Die firma Siemens en Halske het die benodigde masjinerie gelewer om elektrisiteit vir kampverligting op te wek $^{33}$. 


\section{Die kentering}

Met verwysing na die Eerste Volksraadsbesluit van 3 Junie 1897 om werke wat nie dringend noodsaaklik is nie, nie uit te voer nie en om ten opsigte van die bouwerk wat wel uitgevoer moet word spaarsaamheid te betrag, het die Raad nog op dieselfde dag besluit om die beoogde bou van 'n ryskool en ontspanningsgebou in die Artillerie kamp in die hand te wys ${ }^{39}$.

Op 6 Februarie 1898 het die Hoof van Openbare Werke, na aanleiding van 'n vraag deur die Staatsekretaris, 'n opgaaf van geboue ter waarde van meer as $£ 3,000$ $(\mathbf{R} 6,000)$ verstrek wat tydens die afgelope 3 jaar op of naby die Artilleriekamp opgerig is en in dié verband die volgende gegewens verstrek:

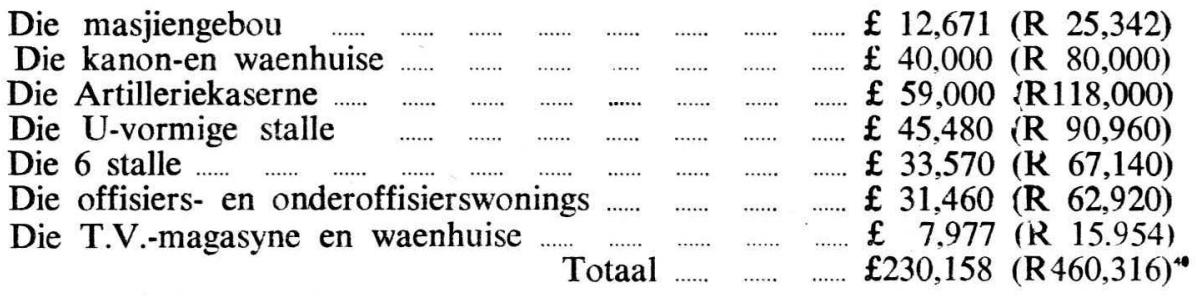

Hierdie syfers gee die leser 'n duidelike indruk van die omvang van hierdie gedeelte van die militêre bouprogram wat deur die regering uitgevoer is. Daar bestaan verder tekeninge van 'n veldtelegrafie-kaserne wat in 1896 beplan was om ten noorde en in die hart van die toenmalige voorplein te verrys, bloudrukke van 'n kombuisgebou ten behoewe van manskappe van die Staatsartillerie en 'n bloudruk van ' $n$ administrasiegebou wat nooit gebou is nie ${ }^{41}$. Hierdie tekeninge en spesifikasies het in 1896 en 1897 gereed gekom, maar die betrokke geboue het nie verrys nie.

\section{Tydens en na die Anglo-Boereoorlog (1899-1925)}

Kort voor die uitbreek van die Anglo-Boereoorlog was die sterkte van die Korps Staatsartillerie 500 man. Die oorlog het gekom en Staatsartilleriste het na die fronte vertrek.

Volgens lt.-kol. S. P. E. Trichardt se herinneringe was die sterkte van die Korps Staatsartillerie ten tye van die uitbreek van die oorlog 400 Rydende of Berede Artillerie, 125 man Vestingartillerie van die 4 Pretoriase forte, 100 man Vestingartillerie van die Johannesburgse fort en 250 reserviste. Met inbegrip van die offisiere was die sterkte ongeveer 900 .

Aan die begin van Junie 1900 , kort voordat die Britse troepe die Transvaalse hoofstad beset het, is die geboue deur vrouens en Bantoes geplunder en kort daarna is die terrein en die geboue deur die veroweraars beset ${ }^{42}$.

'n Nuwe tydperk het in die geskiedenis van die terrein en die kaserne aangebreek wat tot 31 Mei 1914 die hoofkwartier van die South African Command was en saam met ander militêre geboue op die terrein in September of Oktober van dicselfde jaar deur die uniale Departement van Verdediging oorgeneem is ${ }^{43}$.

In 1919 het die distriksingenieur van die Departement van Openbare Werke 'n pleidooi gelewer dat die toenmalige militễre kantore aan Marktstraat (tans Paul Krugerstraat) ontoereikend is en te kenne gegee dat die hoofoffisiere van die U.V.M. na die Artillery Barracks oorgeplaas moet word waarvan die eerste verdieping deur kantoorpersoneel in beslag geneem word wat net so goed na elders oorgeplaas kan word.

Selfs hierdie beoogde verskuiwing sal, aldus die Sekretaris van die Staatsdienskommissie, ontoereikend wees en op grond hiervan beveel hy aan dat daar 'n verdieping aan die bestaande voormalige Artilleriekaserne toegevoeg word. Planne in dié verband is deur die Departement van Openbare Werke opgestel, vervolgens verwerp en in 1924 is besluit om 'n nuwe gedeelte, met 3 verdiepings, aan die voormalige Staatsartilleriekaserne toe te voeg.

Die totale koste van die uitbreiding is op $£ 75,000$ ( $R 150,000)$ beraam en van militêre kant is o.m. voorgestel dat daar, in die nuwe gedeelte, voorsiening vir kantore vir die Minister van Verdediging en sy personeel en die Afdeling Generale Staf op die middelste verdieping gemaak moet word. 


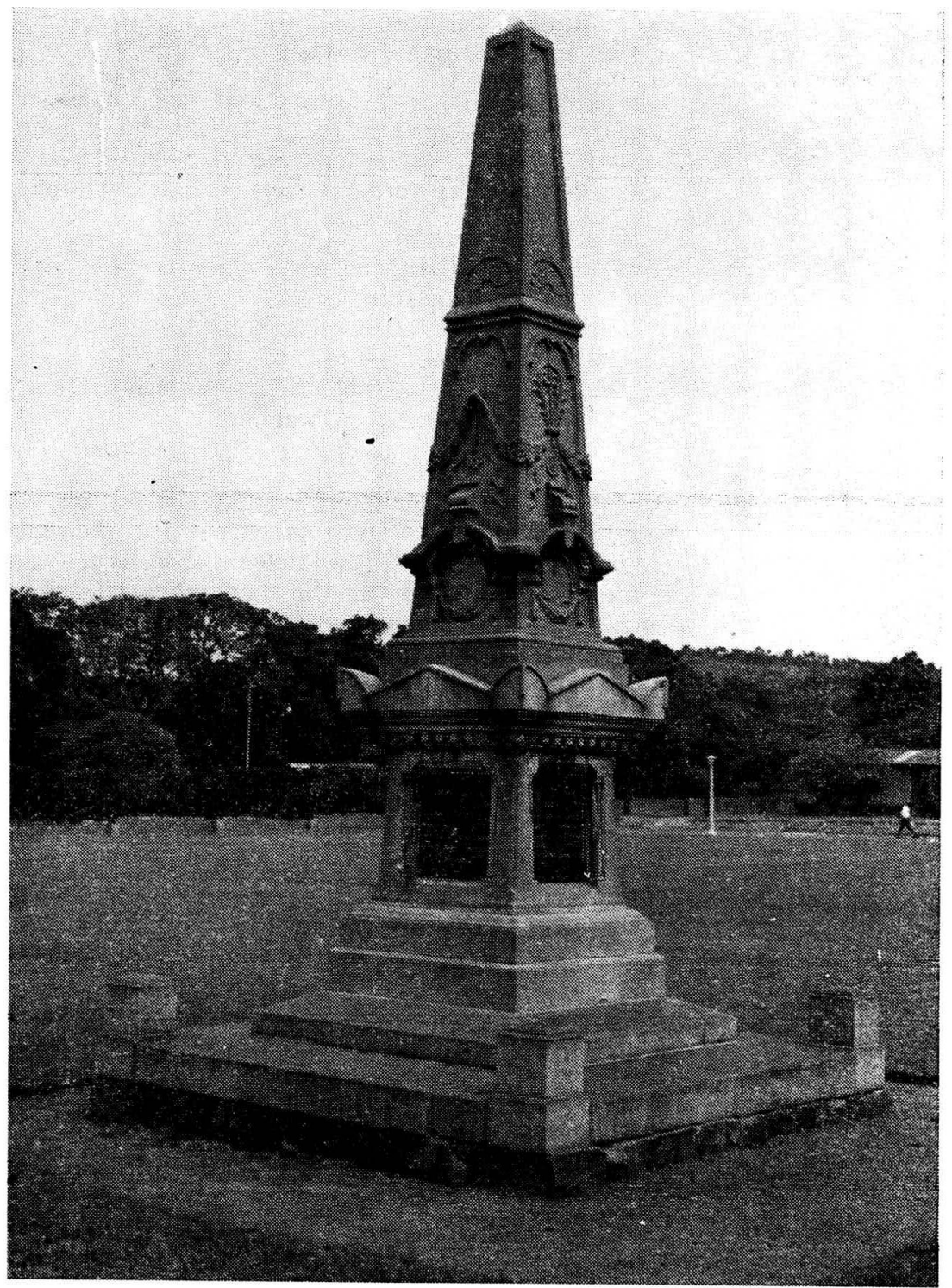

As'n blywende herinnering aan die „vader" van die Korps Staa:sar.illeri' s'aan, voor die Verdedigingshoofkwartier, Potgieterstraat, Pretoria, 'n gedenkteken ter nagedagtenis aan lt.-kol. H. P. N. Pretorius. 'n Geldelike bydrae ter bestryding van die oprigtingskoste is o.m. van Staatspresident S. J.P. Kruger ontvang.

Foto: Militêr-Historiese en Argivale Dienste.

In lasting memory of the "father" of the State Artillery Corps a obelisk dedicated to It.-col. H.P. N. Pretorius stands proudly in front of the Dejence Headquarters, Potgieter Street, Pretoria. A financial contribution towards its erection was, inter alia, received from State President S.J.P. Kruger.

Photograph: Military Historical and Archival Serices 
Altesame is 21 tenders ontvang om die jongste gedeelte van die huidige Verdedigingshoofkwartier te bou. Die tender van die firma J. Brocco en Kie (Bpk.), van Port Elizabeth, is aanvaar en teen 'n koste van $£ 65,000$ (R130,000) is die nuwe gedeelte voltooi en gedurende die eerste helfte van 1927 in gebruik geneem.

Op dié wyse is in elk geval die sloping van die oudste gedeelte van die Verdedigingshoofkwartier voorkom.

Uit bogenoemde besonderhede blyk dat daar 'n tydlank gevaar met betrekking tot verminking van die militêr-histories en argitektonies belangrike Artilleriekaserne bestaan het en op 6 Maart 1925 het L. Moffat, L.V., namens mnr. C. W. Giovanetti, L.V., die Minister van Openbare Werke in die Volksraad gevra of dit onder laasgenoemde se aandag gekom het dat die nuwe Verdedigingshoofkwartier-toevoeging die uitsig op die Artilleriekaserne welke zekere geschiedkundige herinneringen en bouwkundige aanzichten hebben waarvoor een groot gedeelte van de gemeenschap veel voelt sal belemmer.

Minister Boydell het in sy antwoord verklaar dat daar in die voormalige kaserne voorsiening gemaak is vir huisvesting van die Verdedigingshoofkwartier wat in zeer ongelukkige geboue aan Marktstraat gehuisves is en hieraan toegevoeg: die toevoeging zal zijn in de vorm van vleugels aan die voorkant en verbonden met het bestaande gebouw. .. Het nieuwe gedeelte van het gebouw zal in een waardige stijl uitgevoerd worden. Het tegenwoordige gebouw zal op geen wijze veranderd worden, waardoor inbreuk gemaakt zou worden op zijn bouwkundige aangezichten, en over het algemeen is het gehele plan opgetrokken op zodanige wijze, dat de geschiedkundige waarde van de bestaande gebouwen eerder zal verhogen als verminderen.

Op dié tydstip het, aldus die Minister, die boubedrywighede reeds begin ${ }^{44}$.

Die waardes wat in bogenoemde vraag en antwoord beklemtoon is, het in die loop van die jare aanhoudend in belangrikheid toegeneem.

Meer as ooit tevore getuig die militêre geboue in die voormalige Artilleriekamp van die vaste wil en bereidwilligheid van die Regering en die burgers van die Zuid-Afrikaansche Republiek om, ter wille van die behoud van hul vryheid en onafhanklikheid, groot geldelike offers te bring.

$\mathrm{Na}$ Uniewording is die terrein sowel as toentertyd bestaande geboue ingeskakel by die jong verdedigingsorganisasie van die Unie van Suid-Afrika en is, in die twintigerjare van ons eeu, die oue met die nuwe verbind.

Vandag is die saamgesnoerde hoofgeboue 'n gedeelte van die Verdedigingshoofkwartier van die jong en lewenskragtige Republiek van Suid-Afrika.

Militêr-histories, soos hierbo aangedui, sowel as argitektonies is die ouer geboue op die terrein van die Verdedigingshoofkwartier sowel as in die nabyheid hiervan voorbeelde van geboue wat aan 'n spesifieke tydperk in die geskiedenis van ons land en ons volk en sy boukuns herinner.

Aan die slot van hierdie skets word, op grond hiervan, dan ook die vertroue uitgespreek dat die toekomstige geslagte hierdie waardevolle erfstukke met liefde en gepaste eerbied in stand sal hou.

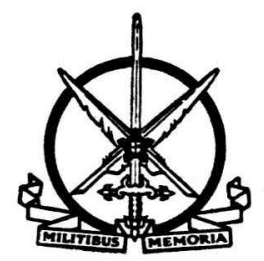




\section{SUMMARY}

Without a doubt the Cape Town Castle is the most valuable military historical building we possess today.

In other parts of the Republic and also in South West Africa there are also many military buildings bearing witness to a proud past. This is inter alia the case in Pretoria where in the early seventies artillery barracks stood at the corner of Paleis and Vermeulen Streets.

The first annexation of the Zuid-Afrikaansche Republiek inter alia led to the establishment of a military camp on the present premises of Defence Headquarters.

After the departure of the British garrison in 1881, the existing buildings were taken into use by the Transvaalsche Rijdende Artillerie.

The dilapidated condition of the barracks in the early nineties, the expansion of the State Artillery Corps and the concomitant reorganisation, the Jameson Raid and the Transvaal military armament programme led to the implementation of the largest military building programme ever undertaken in prewar Transvaal.

In rapid succession stables, gun and wagon sheds and the State Artillery Barracks arose on the site in question. On an adjacent plot the commandant's residence and dwellings for a number of officers were built.

Unfavourable economic conditions accompanied by complaints concerning too expensive an execution of buildings for the account of the State caused that the original military buildings programme in and near the Artillery Barracks was only partially completed.

Stores and wagon sheds for the Field Telegraphy Section and a machine building were completed still before outbreak of the Anglo-Boer war.

Until 1914 the Artillery Barracks served as the British Military Headquarters for South Africa.

Rebuilding and mutilation of the former State Artillery Barracks was prevented although the addition of a new part in front of that existing in 1926-1927, has hidden the graceful front gate previously visible from Potgieter Street.

It is hoped and trusted that the restored buildings will also in future be maintained in good repair by the descendants of a nation proud of all the monuments reminding it of its military past. 


\section{AANTEKENINGE}

i F. J. du Toit Spies, „Bladsye uit die mititêre geskiedenis van Pretorı," Pretoria 18551955, Pretoria, 1955, p. 91.

2 Kantoor Reg. van Aktes, Pretoria. Uittreksel 60/1970 in Transvaal 51-100.

3 Daar kom geen besondere aanduidings op landmeter A. H. Walker se kaart van Pretoria (1875) voor nie.

4 Transvaalse Argiefbewaarplek, Pretoria. - Kaartversameling 3/209, SS 415, waarin R $1640 / 80$, met sketse en korrespondensie. Op F.S. Watermeyer se kaart van die negentige jare is die Artillerie Kamp aangedui op dieselfde plek as waar die huidige V.H.K.terrein tans geleë is (Landmeter-generaalskantoor, Pretoria. Plaaskompilasic R-351). Op landmeter H. M. Anderson se kaart van Julie 1903 is 'n terrein van ruim $167 \mathrm{morg}$ aangedui wat kragtens Uitvoerende Raadsbesluit no. 54, 6 Januarie 1904, vir militêre doeleindes voorbehou is (Ibid., plaasbaek JR-351, waarin LG no. A 3096/04). Gcnoemde terrein is ten naasteby soos volg begrens: Noord-spoorlyn tot 'n punt waar die wesgrens begin en toł die kruin van Magasynheuwel deurloop. Dié kruin vorm die suidelike grens. Oos-Potgieterstraat. Binne hierdie grense is die terrein van die toenmalige Volkshospitaal en die Gevangenisterrein nie vir bogenoemde doeleindes voortbehou nic. Kragtens die Verdediging Begiftigings Eigendom en Rekening Wet (no. 33, 1922), wat voortgevloei het uit die feit dat die Unie van Suid-Afrika vanaf 1 Desember 1921 o.m. die verdediging en verdedigingsmiddels op land vir die verdediging en veiligheid van die Unie aanvaar het, het dic Britse Regering besluit om alle regte, aansprake e.d.m. op sekere militêre terreine en geboue wat op die dergelike terreine geleë is, aan die Unieregering af te staan en oor te dra. In dié verband is o.m. genoem: Artillerie Barakken, Pretoria (32 morg), en Artillerie Barakken, Pretoria Verlenging (130 morg). Oordrag het op 1 Oktober 1914 geskied. (Buitengewone Staatskoerant dl. XLIV, no. 1256, 22 Julie 1922). Ander terreine en geboue in en naby Pretoria o.m.: Die Kantonnement Roberts Heights (ongeveer 1387 morg), Fort Schanskop (ongeveer 34 morg), Fort Klapperkop (ongeveer $21 \mathrm{morg}$ ). Die forte en fortterreine is op 1 Desember 1921 oorgedra.

5 Pretoria 1855-1955, (Pretoria, 1955), pp. 94-96.

6 Transvaalse Argiefbewaarplek, Pretoria, SS 2670, waarin R 633/91, 25.2.1893. Sedert 1890 is daar aanhoudend gekla, soos o.m. uit CR 1761/90 e.a. dokumente onder dieselfde R-nommer blyk.

7 lbid., waarin CR 84/92, 15.1.1892; CR 377/93, 17.2.1893.

8 Ibid., waarin CR 446/93, 24.2.1893.

9 E.V.R. Not., art. 338, 15.6.1893; art. 371, 17.6.1893; art. 371, 17.6.1893.

10 E.V.R. Not., art. 20, 24, 171 en 336 van 1896.

11 Transvaalse Argiefbewaarplek, Pretoria. PW 171, waarin Memorie van Toelichting bij de Schets-Situatic van een Kamp voor 200 man Rijdende Artillerie te Pretoria.

12 Ibid. Die hoofwag is beskrywe as 'n gebou met twee poorte met aan die een kant in kamer vir manskappe en aan die ander kant 'n kantoor en slaapvertrek vir die wagkommandant. Bo die ingang het die ontwerper 'n vertrek beoog waarin, in oorlogstyd, die luitenant van die wag gehuisves word.

13 E.V.R. Not., art. 1475, 24.8.1894. KG 56/2 waarin CR 4578/95.

14 Transvaalse Argiefbewaarplek, Pretoria. SS 2670, waarin CR 1223/95.

15 Ibid., SS 2760, waarin CR 1223/95 en tender no. 768. van 19.6.1895; PW 364 waarin Hoof Publieke Werke - Staatsekretaris, 6.2.1898; PW 168, waarin Bestek en Voorwaarden wegens het bouwen van Twee Paardestallen e.a. voor het corps Staats-Artilleric te Pretoria.

In Maart 1896 was eersgenoemde stalgeboue reeds in aanbou.

16 Ibid., SS 5107, p. 157, UR 13, waaruit URB art. 23, 22.1.1896.

17 Meer besonderhede o.m. in Rewaring van ons erfenisse (red.: Jan Plosger, F. C. L. Bosman, W. H. J. Punt, A. Gordon-Bagnal), Kaapstad, s.j. waarin H. M. Rex .,Die NeoRenaissance Boukens in die Zuid-Afrikaansche Republiek en die Oranje-Vrystaat." 
18 Transvaalse Argiefbewaarplek, KG 122/97. E.V.R. Not., art. 150, 25.5-1879 (verslag Departement Openbare Werke, tenderbedrae onderskeidelik $£ 1843-4-11, £ 3450$ ). UR, band 13, waarin UR-besluit art. 135, 14.1.1896. J. J. Kirkness het in 1897 ook 'n tydelike ammunisiemagasyn gebou wat oorgedra is. 'n Tydelike kaserne en 'n tydelike stal is deur kontrakteurs Winkler en Didden opgerig.

19 Ibid., PW 169, waarin no. 413 (Bestek en Voorwaarden wegens het bouwen van een overkapping tusschen twee kanon- en wagenhuizen), gedateer 17.8.1897. Lengte tussen mure $163^{\prime} 3^{\prime \prime}$, breedte tussen mure 40', klipfondering. Sien ook spesifikasie no. 570, 26.9.1899 in PW 168.

20 Ibid., PW 168, no. 294, Pretoria, 1896 (gedruk).

21 Ibid., UR, band 13, waarin - met verwysing na R 10421/95 - UR-besluit no. 342 2.5.1896.

22 Ibid., KG 74/2, waarin CR 5063/96, 8.7.1896; UR, band 13, waarin URB, art. 489, 10.6.1896 (goedkeuring van tender). Omdat besluit is om die gange van die nuwe kaserne 10 voet i.p.v. 5 voet breed te maak is $£ 2,000$ (R4,000) aan die tenderprys toegevoeg. In die verslag van die Departement van Openbare Werke (E.V.R. Not., art. 160, 25.5.1897) is $£ 59,000$ ( R118,000) aangegee.

23 Ibid., KG 76/1, waarin CR 5282/96. Sien ook CR 6552/96 waarin op 15.9.1896 versoek is om 'n tremspoor na die steenbakkery te mag aanlê.

24 Tydens 'n verbouwing in 1968/1969 het an die lig gekom dat die huidige plankvloere oor die klipvloere gelê is.

25 Transvaalse Argiefbewaarplek. PW 146, waarin Week-Rapporten.

26 Ibid. PW 350, p.124. HPW - The Franco Italian Building Co., 1.3.1897. Volgens MR 986/97, in PW 146, was C. Simon die plaaslike bestuurder van die nuwe maatskappy. In PW 1966 is Bestek en Voorwaarden voor het verrichten van eenige werkzaamheden ald Woning voor de Kommandant a/h Artilleriekamp te Pretoria, 1897. 27.8.1897. Sien ook PW 170, no. 459, April 1898 (kamer).

27 Ibid., PW 146, waarin sertifikate R 7142/96. PW 350, waarin PR 4514/97 tot tydverlenging van 6 maande.

28 E.V.R. Not., art. 160, 25.5.1897.

29 Transvaalse Argiefbewaarplek. KG 201/3, waarin verslag.

30 E.V.R. Not., art. 160, 25.5.1897.

31 Ibid., art. 160, 25.5.1897 (verslag).

32 Ibid, art. 168, 26.5 .1897 (C. J. Tosen, Piet Retief, J. du P. de Beer, Waterberg; S. P. du Toit, Wolmaranstad; L. J. Meijer, Vryheid e.a.).

33 Ibid., Art. 234, 3.6.1897.

34 Transvaalse Argiefbewaarplek. PW 168, waarin no. 310. Die bloudruk is onder die kaartversameling, aangedui as S3/1235. Sien ook: SS 5441, waarin R 6469/96 (met verslag van die tenderkommissie) en PW 169, waarin spesifikasie no. 405.

35 Ibid., PW 169, waarin spesifikasie no. 365. Die tekeninge is nie opgespoor nie, maar die bestaande voorgewel kom ooreen met dié van die beplande keukengebouw (kaartversameling $S$ 3/1239).

36 Ibid., UR, deel 14, art. 276, 23.4.1897.

37 Ibid., PW 169, waarin spesifikasie no. 402 (fondering vir ketels, Julie 1879). Tenderbedrag $£ 1,239$ (R2,478). Sien ook: UR, deel 16, art. 567, 21.6.1898.

38 Ibid., SS 7098, waarin R 3562/98, met vermelding van URB art. 320/98 en 37/99 insake aanstelling van 'n hoofmasjinis, 'n masjinis-werktuigkundige en 'n stoker. Die Commissie i.v.m. uitvoering van zeker Gouvermentswerk het ook 'n mate van seggenskap i.v.m. die bou gehad soos blyk uit LA 645 (SS Kabinet - Reg. 1899), waarin melding gemaak is van die ontvangs van GR 611/98, 24.5.1898).

Die geskiedenis van die masjiengebou is nagegaan tot 1924. In dié jaar is verklaar dat die gebou in 'n goeie toestand verkeer, dat die boonste verdieping deur die Pretoria Regiment vir voorrade gebruik word en dat die masjinerie nog in die gebou aanwesig is. Terselfdertyd is besluit om die gebou nie af te breek nie 
39 E.V.R. Not., art. 233, 3.6.1879.

40 Transvaalse Argiefbewaarplek. Pw 364. In totaal van alle bouwerke in die Z.A.R.: $£ 940,598(\mathbf{R} 1,881,196)$.

41 Ibid., PW 168, waarin no. 319 (veldtelegrafie-kaserne), S 3/1239 met bybehorende spesifikasie no. 378 (kookinrigting) in PW 149 en PW 187, S 2/237 (kaartversameling, admin. gebou). Korrespondensie aangaande die ryskool in SS 6297 ( $R$ 4440/97), en kaart S 1/81. Oor die ontspanningsgebou: PW 168, waarin spesifikasie no. 312, gedateer 25.3.1896.

42 Ibid. Prellerversameling, band 14, „Geschiedenis Werken en Streven van S. P. E. Trichardt, Luitenant-kolonel der Vroegere Staatsartillerie ZAR Door hemzelve bescnreven," Middelburg, April 1903, p. 172, p. 244.

43 Sentrale Argiefbewaarplek. PW 12344, waarin o.m. CRSA 15630/24 (DBO), 28.8.1914 en verdere korrespondensie van 12.8.1914, 30.9.1914, 7.10.1914. Offisiershuise is aan Z.A.B.S.-offisiere toegewys. Die voormalige kommandantswoning is deur kol. Dawson betrek.

44 Debates of the House of Assembly, Vol 3, 13.2-15.4.1925, 6.3.1925, p.633. 


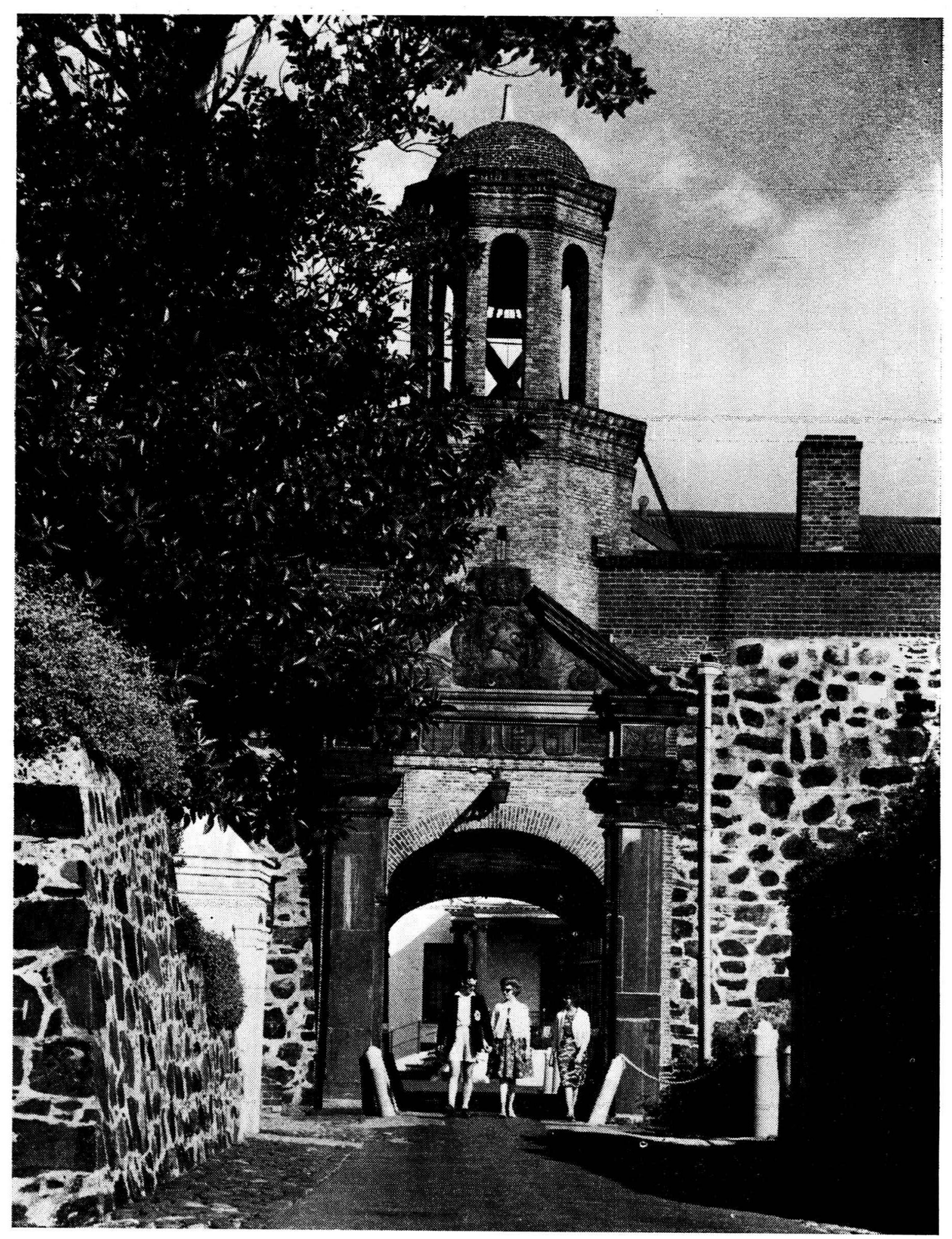

Die Kasteel, Kaapstad. Die indrukwekkende hoofingang.

Kopieregfoto: SATOER, Pretoria.

The Castle, Cape Town. The impressive main entrance.

Copyright photograph: SATOUR, Pretoria. 